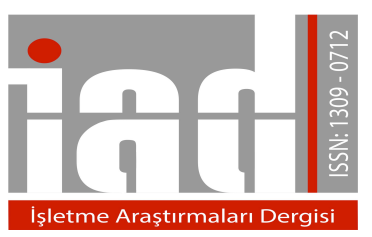

Journal Of

Business Research

Turk

www.isarder.org

\title{
Tüketimde Sinik Tutum: Tüketici Sinizminin Sebep ve Sonuçları \\ Cynical Attitude in Consumption: The Antecedents and Consequences of Consumer Cynicism
}

\author{
Esra GÜVEN \\ Celal Bayar Üniversitesi \\ Gördes Meslek Yüksekokulu \\ Manisa, Türkiye \\ esra0505@gmail.com
}

\section{Özet}

Tüketici davranışlarının marka geleceği konusunda son derece belirleyici olduğu günümüzde, tüketici zihninde marka hakkında oluşan tutumlar da aynı oranda önem kazanmaktadır. Tutumların büyük ölçüde tecrübelerden kaynaklandığı fikrinden hareketle, tüketiciler yaşadıkları tatminsizlikler ve olumsuzluklar sonrasında marka hakkında olumsuz birtakım tutumlara sahip olabilmektedirler. Konu önceki tecrübeler, güven kaybı ve de tatminsizlikler olduğunda, örgütsel davranış konusunda son yıllarda dikkat çeken konulardan birinin de 'sinizm' olduğu görülmektedir. Literatür sinizmin bilişsel, duygusal ve davranışsal bileşenlerden oluşan negatif bir tutum olduğu konusunda uzlaşmaktadır. Sinizm yaygın olarak şüphe ve güvensizlik duygularıyla iç içe olmasının yanında tatminsizlik, yabancılaşma ve direnmeye kadar uzanan sonuçlara da sahip bir kavram olarak bilinmektedir. Buradan hareketle karşılıklı bir güven ilişkisini gerektiren marka-tüketici ilişkilerinde de bu güvenin zarar görmesiyle birlikte tüketicide oluşabilecek bir 'tüketici sinizmi'nden bahsetmek mümkün olacaktır. Bu çalışmada genel sinizm kavramından yola çıkarak, spesifik bir sinizm türü olan tüketici sinizmi hakkında literatür taraması yapılmış ve bu kavramın gerek içeriği gerekse de sebep ve sonuçları ortaya konulmaya çalışılmıştır. Aynı zamanda, bu tutumun işletmeler açısından olası etkileri hakkında bilgi verilerek marka tüketici ilişkilerinde farklı bir bakış açısı kazandırılmaya çalışılmıştır. Bu çalışmada tüketici sinizmi konusunda yapılabilecek sonraki çalışmalara bir altyapı sağlaması da amaçlanmaktadır.

Anahtar Kelimeler: Sinizm, Tüketici Sinizmi, Güven, Şüphecilik, Tatminsizlik

\section{Abstract}

In our modern world where consumer behaviours are essential for the future of the brand, the attitudes in the minds of consumers are getting more and more important. As attitudes are largely resulted from the experiences, consumers can have negative attitudes following the negative experiences with the brands. When it comes to negative experinces and particularly dissatisfactions, a newly emerged concept in organizational behaviour comes to the fore 'cynicism'. The most essential studies in the field are 
agreed that cynicism is a negative attitude that has cognitive, affective, and behavioural components". Cynicism is commonly related to suspicion, mistrust, skepticism, and distrust of agent's motives, as well as reactions of dissatisfaction, alienation, and resistance or even hostility towards the agent. Classification of these related constructs according to the cognitive, affective and behavioural components of attitude defines the scope of cynicism represented in the literature. Realizing that company-customer relationship is also in need of tust and when it is broken, the consumer develops a negative attitude toward the product or the company. This negative attitude can be called as 'consumer cynicism'. This study, setting out from the general cynicism concept, deals with a general literature review about a specific kind of cynicism, known as 'consumer cynicism' and aims to put a general frame about the content, the antecedents and the consequences of consumer cynicism. The study also tries to prepare a base review for the future research on consumer cynicism which is coming to the fore in the marketing field every other day.

Keywords: Cynicism, Consumer Cynicism, Trust, Scepticism, Dissatisfaction

\section{Giriş}

Tüketim alışkanlıklarının her geçen gün değiştiği günümüz dünyasında tüketicilerin belirleyici rolü de buna bağlı olarak sürekli artmaktadır. Günümüz tüketicileri hemen hemen her türlü ürün ya da hizmet konusunda pek çok alternatif arasından birisini tercih etmekte ve bu sayede de tercih edilen ürünün rakiplerinden bir adım öne geçmesini sağlayabilmektedirler. Tüketici tercihlerinin böylesine önemli olduğu bir dönemde artık marka ve tüketici arasındaki ilişkiler de son derece önemli hale gelmektedir. Bu iki taraf arasındaki ilişkilerin kalitesi arttıkça taraflara sağladığı katkılar da aynı ölçüde artabilmektedir. Özellikle de sektöründeki pek çok rakibi karşısında bir avantaj elde etmeye çalışan marka ya da işletmeler açısından bakıldığında, tüketicilerle kurulan ilişsinin önemi çok daha değerli hale gelmektedir.

Pazarlamacıların ana amaçlarından birisi ürün ve hizmetleri konusunda rakiplerinin üstünde bir öneriyle piyasada farklılaşmış bir konum elde edebilmektir. $\mathrm{Bu}$ amacın hayata geçebilmesi için de müşteriler tarafından iyi bilinmek gerekmektedir. Bir diğer ifadeyle markanın belirli özellik ve avantajlara sahip olduğunu müşteri zihninde doğru konumlandırabilmek önem kazanmaktadır. Özellikle de tüketicilerin böylesine farklı alternatiflere sahip olduğu günümüz piyasalarında, markalar müşterilerin güvenini kazanabilmek ve karar süreçlerinde destekleyici olabilmek durumundadırlar (Delgado ve Aleman, 2006:187). Coca Cola gibi ikonik hale gelmiş önemli markalar, marka ve tüketicinin karşılıklı ilişki halinde olması gereken partnerler olması gerektiğini düşünmekte ve buna uygun bir strateji izlemektedirler. Bu ilişki de aynen iki insan arasındaki ilişki gibi karşılıklı etkileşime ve güven duygusuna ihtiyaç duymaktadır (Funder vd, 2015: 36).

Günümüz tüketicileri her gün belki onlarca tüketim tecrübesi yaşamakta ve bu tecrübeler sonrasında markalar hakkında bir takım tutumlar geliştirme yoluna gitmektedirler. Yaşanan bu tecrübelerin sonraki tüketim davranışlarında belirleyici olduğu göz önüne alındığında, tüketicilerde güven kaybına yol açacak deneyimlerin markalar açısından uzun vadede sebep olacağı zararların boyutları da görülebilecektir. İkili ilişkilerin kalitesi konusunda en belirleyici faktörlerden birisi olan güven faktörünün, tüketici ve marka arasındaki ilişkilerde de aynı derecede etkili bir faktör olduğu değerlendirilmektedir (Hess ve Story, 2005:313). Tüketici marka ilişkilerinde 
sadakatin ve sürekliliğin sağlanabilmesi açısından bu ilişkinin güven temelinde yürümesi gerektiği de kabul edilmelidir.

Her gün birçok farklı şekilde tüketim ilişkisine giren bireyler, bu ilişkilerinde pek çok defa tatminsizlikler yaşamakta, şikayette bulunmakta, pişmanlıklar yaşamakta ve de bunlar sonucunda edindiği tecrübelerle piyasadaki ilişkilerine yön vermektedir. Piyasada edinilen olumsuz tecrübeler, tüketicilerde zamanla güven kaybına ve kendini çekmeye sebep olmakta ve marka ya da firmaya karşı şüpheci davranışlara yol açmaktadır. Gerek marka ile doğrudan yaşanılan ilişkilerin gerekse de marka mesajlarının tüketiciler üzerinde zamanla yarattığı bu olumsuz izlenimler ve sonrasında oluşan tutumlar ve sonuçları tüketici davranışları açısından dikkatle ele alınması gereken konulardan birisidir. Konu önceki tecrübeler, güven kaybı ve de tatminsizlikler olduğunda, örgütsel davranış konusunda son yıllarda dikkat çekmeye başlayan sinizm kavramı ön plana çıkmaktadır. Ağırlıklı olarak çalışanlar ve çalıştıkları kurum arasındaki ilişkiyi temel alan sinizm araştırmalarından (Dean, 1997; Abraham, 2000) yola çıkarak, bu kavramın tüketici marka ilişkilerine rahatlıkla uyarlanabileceği değerlendirilmektedir (Devlin ve McKechnie, 2008; Gillani vd., 2011; Brants, 2013). $\mathrm{Bu}$ konunun yabancı literatürde de henüz çok yeni bir konu olduğu göz önüne alındığında önümüzdeki yıllarda yaygın şekilde çalışılma imkanı olacağ düşünülmektedir.

Örgütsel davranış literatüründe geniş bir literatür ve içerik zenginliğine sahip olan sinizm kavramı, temel itibarıyla güvensizlik, tatminsizlik ve karşılanmamış beklentilerle ilişkilendirilmektedir (Chu ve Chylinsky, 2006:1). Öte yandan Abraham (2000:269) sinizm ile ilgili temel inanışın, dürüstlük, adalet ve sadakat prensiplerinin, bireyin kendi kişisel ilgilerine feda edilmesi olduğunu ifade etmektedir.

Temelinde sosyal hayatın olmazsa olmazı sayılabilecek olan dürüstlük ve adalet gibi prensiplerin ihlalinin yattığ 1 ve bunun da zamanla güvensiz birey ve de topluma sebep olduğu sinizm kavramının tüketim piyasası için de son derece önemli olabileceği değerlendirilmektedir. Bu kavramın içeriğinden yola çıkarak yakın dönemlerde yapılan bazı pazarlama araştırmaları bu kavramın tüketicilerle de yakından ilgili bir yapıya sahip olduğunu göstermektedir. Zira sinizmin temelindeki en temel eksiklik olan güven faktörü, marka ve tüketici arasında olmazsa olmaz bir unsurdur. Bunun sonucunda da tüketicinin markaya karşı güven duygusunu kaybetmesi konusu sebep ve sonuçları yönüyle pazarlama için önemli bir konu olarak dikkat çekmektedir.

$\mathrm{Bu}$ kavram gerek sebepleri gerekse de sonuçları itibarıyla marka tüketici ilişkilerine yön verebilen ve çözülemediği takdirde marka için son derece yıkıcı olabilecek davranışları içine almaktadır. Bu bağlamda konunun dikkatle ele alınması ve bu konuda genel bir çerçeve ortaya konulması hem pazarlamacılar hem de literatür açısından yararlı olacaktır. $\mathrm{Bu}$ çalışma, tüketici sinizmi konusunda yapılan diğer çalışmalardan farklı olarak, tüketici sinizmini sebep ve sonuçlarıyla ele almakta ve bu konuda ortaya konulan modelleri bir araya getirerek konuya bütüncül bir perspektif katmayı amaçlamaktadır. Bu çalışmada kullanılan literatür taraması tamamen tüketici sinizmi konusunda yapılan çalışmaları kapsamakta ve çalışmaların ortaya koyduğu sonuçları bir bütün halinde sunmaktadır. 


\section{Sinizm ve Tüketici Sinizmi Kavramı}

Son yıllarda birçok araştırmacı tarafından ele alınan ve tutum ile yakından ilişkili olan sinizm konusu sosyal bilimlerin pek çok alanında araştırma konusu olmaktadır. Aynen tutum gibi içinde bilişsel, duygusal ve davranışsal boyutlara sahip olan sinizm kavramı, bu içeriği yönüyle gerek bireylerin gerekse de bireylerle doğrudan ilgisi olan örgüt ve işletmeler açısından da dikkatle ele alınması gereken konulardan birisidir. Temelleri çok eskilere dayanan bu kavramın ilk ortaya çıktığı yıllarda da karşılıklı ilişkiler boyutuyla ele alındığı görülmektedir.

Bir yaşam tarzı ve düşünce ekolü olarak sinizmin Eski Yunanistan'da ortaya çıktığı bilinse de bir terim olarak sinizmin (cynicism) nereden geldiği konusunda tartışmalar vardır. Bazı araştırmacılar, sinizm eğilimi sergileyen insanların fikirlerini bir havlama (bark) şeklinde ifade ettiklerini ve de davranışlarında da saldırgan bir tarzı benimsediklerinden yola çıkarak bu terimin yunanca köpek anlamına gelen "kyon"dan geldiğini öne sürmektedirler (Roberts, 2006:4). Başka bir grup araştırmac1 ise bu terimin kaynağı olarak Siniklerin ilkokullarının bulunduğu yer olan Atina yakınlarındaki bir kasaba olan Cynosarges'den geldiğini söylemektedirler (Fuller 1931'den akt Dean vd, 1998:342). Sinizm teriminin ilk kaynağ 1 konusunda tam bir uzlaşı olmasa da, sinizmin ilk ortaya çıtığı yıllarla günümüzde kazandığı anlam arasında önemli farklılıklar olduğu görülmektedir. Eski Yunan'da kendini toplumdan soyutlama ve idealist bir hayat yaşama şeklinde bir ekolü ifade eden bu kavram günümüzde daha çok güven kaybı ve bunun getirdiği olumsuz tutumlarla ilişkilendirilmektedir. $\mathrm{Bu}$ konuda yapılan tanımlamaların incelenmesi konunun günümüze bakan yönünü anlamaya yardımcı olacaktır.

Sinizm konusunda literatürde pek çok tanım görülmektedir. Bu tanımlardan birine kaynaklık eden Oxford English sözlüğü (1989) sinizm kavramını tanımlarken, 'insan güdü ve eylemlerinin iyiliği ya da dürüstlügüne inanmama eğilimi sergileme ve bunu alaycı söz ve davranışlarla gösterme' olarak tanımlamaktadır. Bu tür eğilimlere sahip bireyler de 'sinik' bireyler olarak isimlendirilmektedir. Webster' Revised Unabridged Dictionary, sinikleri tanımlarken 'asık suratlı, öfkeli konuşan, tenkitçi ve kavgacı özelliklere sahip bireyler' ifadesini kullanmaktadır. Bu çalışmada geçen 'sinik' kavramı, TDK sözlügünde ise iki anlamda kullanılmaktadır. İlk anlamında bu kavram 'sinmiş, pusmuş, yılmış' bireyler olarak tanımlanmaktadır. Bu ifadenin 'sinmek' kökünden türetildiği açıktır ve bu çalışmanın konusuyla ilgisi bulunmamaktadır. İkinci anlamda ise, sinizm taraftarı kimse ya da görüş şeklinde bir anlam verildiği görülmektedir. $\mathrm{Bu}$ ikinci anlama dayanarak bu ifadenin gerek çalışma başlığında gerekse de çalışmanın içinde 'sinik' olarak kullanılmasının uygun olacağı değerlendirilmiştir

Sözlüklerin verdiği bu tanımlamaların sinizm kavramını daha çok bir karakter olarak ele aldığ1 ve sinizmin oluşumundan çok görünen yüzüne vurgu yaptığ1 görülmektedir. Literartürde bir karakter özelliğinden çok bir tutum olarak kabul gören bu kavramın daha net anlaşılabilmesi için bu alanda yapılan çalışmaların ortaya koyduğu tanımlamalara da ihtiyaç duyulmaktadır.

Kişiliğin psikososyal yönleri üzerine yapılan araştırmalar, sinizmi sinik düşmanlık olarak tanımlamışlardır. Bu yapıyı sabit bir karakter olarak değerlendirme eğilimindeki Cook ve Medley'e göre sinizm, sinirlenmeye açık olma, gücenme ve güvensizliğin bir kombinasyonu şeklinde tanımlanmaktadır (Smith vd, 1988:526). Bu konuda önde gelen araştırmacılardan olan Abraham (2000:8) ise sinizm ile ilgili temel inanışın, dürüstlük, 
adalet ve sadakat prensiplerinin bireyin kendi kişisel ilgilerine feda edildiğini ifade etmektedir. Bu kendi merkezliliğin gizli gündem ve aldatmalara dayalı eylemlere yol açtığına da dikkat çekmektedir. Buradan anlaşılacağı üzere sinizmin en temelinde yatan sebebin, karşılıklı ilişkilerde öncelikli bir beklenti olan dürüstlük, adil olma ve sadakat beklentilerinin bir hayal kırıklığı ile ve sonucunda aldatılma hissi dikkat çekmektedir. $\mathrm{Bu}$ konudaki temel tanımsal yaklaşımlar yaygın olarak örgütsel, sosyal ve politik davranış sinizmi çalışmalarından alınabilmektedir. Bu çalışmalarda sinizm güvensizlik, tatminsizlik ve karşılanmamış beklentilerle ilişkilendirilmektedir (Chu ve Chylinsky, 2006:1).

$\mathrm{Bu}$ temel tanımlamalardan da anlaşılabileceği üzere, sinizm toplumsal hayatın her alanında görülebileceği gibi, insanların tüketim davranışlarında da kendini gösterebilecektir. Yakın dönemlerde yapılan bazı pazarlama araştırmaları da bu kavramın tüketicilerle de yakından ilgili bir yapıya sahip olduğunu ortaya koymaktadır. Zira sinizmin temelindeki en temel eksiklik olan güven faktörü, marka ve tüketici arasında olmazsa olmaz bir unsurdur. Bunun sonucunda da tüketicinin markaya karş1 güven duygusunu kaybetmesi konusu sebep ve sonuçları yönüyle pazarlama için önemli bir konu olabileceği değerlendirilmektedir. Bu konuda yapılan çalışmalar ve vurgu noktalarının incelenmesi bu kavramın anlaşılabilmesine katkı sağlayacaktır. Buna ilişskin olarak da Tablo 1'de tüketici sinizmine dair literatürdeki tanımlar bir arada verilmektedir.

\section{Tablo 1. Tüketici Sinizmi Tanımları}

\begin{tabular}{|l|l|}
\hline Yazar(lar), Yıl & Tanımlar \\
\hline Laczniak, 2001 & $\begin{array}{l}\text { İşletmelerin boş vaatler peşinde olması ve dürüstlükten yoksun olmalarına } \\
\text { dair bir inanıştır. }\end{array}$ \\
\hline Chu ve Chylinsky, 2006 & $\begin{array}{l}\text { Tüketicilerdeki şüphenin, firmaların sadece kendi çıkarlarının peşinde } \\
\text { olduğu düşüncesiyle birleştiği ve sonrasında piyasaya yöneltildiği bir } \\
\text { tutumdur. }\end{array}$ \\
\hline Helm, 2006 & $\begin{array}{l}\text { Tüketicilerin piyasadaki davranışlarına yön veren birtakım tutarlı inançlar ve } \\
\text { negatif duygulardır. }\end{array}$ \\
\hline Mikkonen vd., 2011 & $\begin{array}{l}\text { Piyasaya ya da piyasadaki kurumlara karşı şüphe hayal kırıklığ1 ve } \\
\text { aldatılmaya çalışıldığının farkına varmaya yol açan bir tür psikolojik telafi } \\
\text { stratejisidir. }\end{array}$ \\
\hline Dolen vd., 2012 & $\begin{array}{l}\text { Firmanın açık ya da gizli sebeplerine inanmama ya da diğer bir deyişle } \\
\text { firmanın tüketicilerin istek ve ihtiyaçlarına neredeyse hiç ilgi duymadığı, } \\
\text { bunun yerine kendi çıarlarını kolladığına dair bir düşüncedir. }\end{array}$ \\
\hline
\end{tabular}

Halen araştırma aşamasında bir konu olan tüketici sinizmi kavramının literatüre kazandırılması konusunda Helm'in yaptığı çalışma dikkat çekmektedir. Helm'in tüketiciler üzerinde yaptı̆̆ bu çalışmaya göre, bazı tüketiciler piyasadaki davranışlarına yön veren bir takım tutarlı inançlara ve negatif duygulara sahiptirler. $\mathrm{Bu}$ inanç, duygu ve davranışlar sinizmin temel elementleriyle uyuşmakta ve tüketicilere özel bir sinizm tarzının da göstergesi olmaktadır (Helm, 2006:3).

'Adil Ticaret' konusunda sinizmi ele alan Gillani ve arkadaşlarının (2011:3) ise tüketici sinizmini, 'işletmelerin dürüstlükten yoksun olmalarına dair yaygın inanış ve 
belirli markalara karşı uzak durma ya da kendini çekme davranışı' şeklinde tanımladığı görülmektedir.

Yine tüketici sinizmi konusunda araştırmalar yapan Chu ve Chylinsky (2006:1), tüketicilerdeki firmaya ve tüm piyasaya yönelik bir şüphecilik bulgusuna ulaştığ çalışmada, tüketici sinizmi kavramını 'tüketicilerdeki şüphenin, firmaların sadece kendi çıkarlarının peşinde olduğu düşüncesiyle birleştiği ve sonrasında piyasaya yöneltildiği bir tutum' olarak tanımlamaktadır. Aynı araştırmacılar, 2010 yılında yaptıkları bir diğer çalışmada tüketici sinizmi kavramını, sinizmin temel bileşenleri olan duygusal, bilişsel ve davranışsal boyuta göre bir sınıflandırmaya tabi tutmuşlardır. Bu sınıflandırmada sinizmin bilişsel boyutunda şüphe, güvensizlik, kuşku ve itimatsızlık kavramlarına dikkat çekilirken, sinizmin duygusal boyutunda yabancılaşma ve tatminsizlik kavramları ele alınmaktadır. Çalışmada sinizmin davranışsal boyutunda ise direniş ve düşmanlık kavramlarından bahsedilmektedir (Chylinsky ve Chu, 2010:780).

Mikkonen ve arkadaşları (2011:101) ise yaptıkları çalışmada tüketici sinizmini bir savunma mekanizması vurgusuyla ele almakta ve bu kavramı 'piyasaya ya da piyasadaki kurumlara karşı şüphe, hayal kırıklığı ve aldatılmaya çalışıldığının farkına varmaya yol açan bir tür psikolojik telafi stratejisi' olarak tanımlamaktadırlar. $\mathrm{Bu}$ araştırmacılara göre tüketici sinizmi basit bir eleştiriden çok, radikal bir tutum olarak değerlendirilmektedir.

Dolen ve arkadaşlarının (2012:306) ise, tüketici sinizminde firma çıkarcılığı inancına odaklandığı görülmektedir. Bu araştırmacılar yaptıkları tanımlamada tüketici sinizminin 'firmanın açık ya da gizli sebeplerine inanmama ya da diğer bir deyişle firmanın tüketicilerin istek ve ihtiyaçlarına neredeyse hiç ilgi duymadığı, bunun yerine kendi çıkarlarını kolladığına dair bir düşünce' olarak ifade edildiği görülmektedir. Dolen ve arkadaşlarına göre tüketici sinizmi negatiflikle ilişkili ve bir kişi, kurum ya da işletmenin dürüst, bencil ve sadece kendini düşündüğü inanışını yansıtan bir kavramdır. Sinik bir tüketici kendini bu negatiflikten koruma amacıyla geri çekilme ve uzaklaşma hareketi sergilemektedir (Dolen vd, 2012:308).

Laczniak ve arkadaşları da bu bağlamda bir değerlendirmeyi tercih etmekte ve tüketici sinizminin işletmelerin boş vaatler ve dürüstlükten yoksun olmasına vurgu yapan bir inanışı yansıttığını ifade etmektedirler. Bunun yanında tüketicilerin firmalarla olan ilişkilerinde sıklıkla kızgınlık duydukları ve tatminsizlikleri konusunda firmaya tepki hissi içinde oldukları, beğenmedikleri şirketleri boykot edebildikleri ya da diğer insanları bu firmalardan alışveriş yapmamaları konusunda uyardıklarına dikkat çekilmektedir. (Laczniak vd., 2001:69).

Marka ve işletmelerin etik dışı davranışları konusunun tüketicilerde sinik eğilimlere yol açabildiği ve tüketici sinizminin de bu etik dışı davranışlara bir tepki koyma ve direnme konusunda etkili olduğuna dikkat çeken araştırmalar da vardır. Tüketici sinizminin bilişsel ve davranışsal boyutunu inceleyen araştırmacılardan birisi olan, Detert(2008) sinizm ve etik olmayan kararlar arasında pozitif bir ilişki sonucuna ulaşmıştır. Chowdhury ve Fernando (2014:682) da bu araştırmanın sonucundan yola çıkarak sinizmin etik dişılığa bir tepki olarak ortaya konulan tüketici eylemlerine dair olumlu algılara yol açabileceğini ifade etmektedir. Mikkonen ve arkadaşları tüketici sinizminin, Michael Foucault un 'politics of self'in de dile getirdiği sosyal eleştiri ve direnişin bir şeklini temsil ettiğine dikkat çekmektedir. Çalışmada tüketici sinizmi kavramı, sadece tüketim toplumunun sosyal düzenine karşı bir tepki değil aynı 
zamanda bu düzenin beraberinde getirdiği subjektif normlara karşı ciddi bir direniş olarak ifade edilmektedir (Mikkonen vd., 2011:100). Buradan hareketle, tüketici sinizminin etik dışı davranışlardan ortaya çıkabildiği ve sonucunda da bu tür davranışlarla bir mücadele yolu olarak da işlev görebildiği söylenebilecektir.

Konu tüketici ve marka ilişkisi olunca bu ikilinin doğrudan karşı karşıya geldiği reklam konusu da tüketici sinizmi noktasında önemli hale gelmektedir. Zira günümüzde reklam içerikleri ve bu içeriklerin gerçeği yansıtmadığı konusunda ciddi eleştiriler yapılmaktadır. Özellikle de tüketici sinizminin karşılanmamış beklentilerle yakından ilişkisi göz önüne alındığında, tüketici beklentilerini yükselten reklam unsurunun tatminsizlikle doğrudan bir ilişkisi olduğu görülebilecektir. Yükseltilmiş beklentilerin, sonrasında yaşanan tatminsizliklerde çok önemli payı olabileceği ve dolayısıyla da reklamın tüketicilerdeki sinik eğilimler üzerinde etkili olabildiği değerlendirilmektedir.

$\mathrm{Bu}$ konuda yapılan araştırmalar reklam bağlamında ele alındığında, reklam mesajlarına yönelik bir tüketici şüpheciliğinden bahsedilmekte ve bu kavram da sinizmin 'inanmama' (üç boyuttan bilişle ilgili) bileşeni ile ilgili olmakla beraber, sinizmin aşırı negatif etkilerini içermemektedir. Sinikler aynı zamanda şüpheci olabilmekte ve bu tip bireylerin yeni fikirlere kapalı olmak ve hayal kırıklıkları sonrası dikkatli olmaya başlamak gibi özellikler gösterdiği görülmektedir (Kanter ve Mirvis, 1989'dan akt. Gillani vd, 2011:3). Ayrıca bu bireyler otoriteye karşı olumsuz ve güvenmeyen tutumlar, değişimin liderlerine güven kaybı, insan davranışlarına karşı genel bir negatif algı, başkalarına güvenmeme ve toplum ve birey arasındaki sosyal sözleşmelerin çiğnendiğini düşünme özellikleri de göstermektedir. Özetle tüketici sinizmi şirketlerin dürüstlükten yoksun olduğu inancı ve belirli markalardan kaçınma gibi negatif duygularla karakterize edilebilmektedir (Abraham, 2000:270).

Tüketici sinizmine dair yapılan tüm bu çalışmaların vurgu noktalarına bakıldığında, beklentiler ve sonrasında tatminsizlikler ve sonucunda oluşan güvensizlik, negatif tutumlar dikkat çekmektedir. Bu negatif tutumların yansımalarının ise bu olumsuz tecrübeler hakkında etrafındakilerle konuşmaktan, tepki eylemlerine kadar uzanabildiği görülmektedir. $\mathrm{Bu}$ sürece sistematik bir bakış açısı kazandıran araştırmacılardan Odou ve Pechpeyrou (2011:1801-1804) yaptıkları çalışmada tüketici sinizmini Şekil 1'de görüldüğü gibi dört farklı kategoriye ayırmışlardır. Bu kategorilerden birisi olan savunmacı sinizm'de abartılı ve her ikna teşebbüsüne karşı küresel bir güvensizlik söz konusu olmakta, herkesten şüphe duyulmakta ve bu yolda iyi niyetli olanların bile isteğini kırma davranışı dikkat çekmektedir.

Diğer bir tüketici sinizmi türü olan saldırgan sinizmde ise bireyin kendi amaçları adına özgürleşme ve kritik bir yıkıcılık söz konusudur. Bu her iki sinizm türünde tüketim ideolojisinin sorgulanması yerine piyasayla başedebilme çabası vardır. $\mathrm{Bu}$ çabada savunmacı sinikler piyasayı duygusal şekilde yorumlarken, saldırgan siniklerde daha pragmatik ve mücadeleci bir tarz görülmektedir. Üçüncü tüketici sinizmi türü olan yıkıcı sinizm ise, piyasayı hedef alan provokatif ve kimi zaman tutarsız uygulamaları içine almaktadır. Burada temel amaç, tüm diğer tüketicilere piyasanın kodlarını açıklamak ve aldatılmaya çalışıldıklarını göstermektir. Etik sinizm adı verilen son tüketici sinizmi türünde ise, tüketici sadece kendi değer ve yargılarına güvenmekte ve bunun dışında tüm diğer yargıları reddetmekte ve bir direniş sergilemektedir. $\mathrm{Bu}$ direnişin tüketim karşıtlığ 1 bir harekete yol açmamasının temel sebebi olarak ise böyle bir harekette etik tüketici sinizminde reddedilen ortak bir inancın söz konusu olmasıdır. 


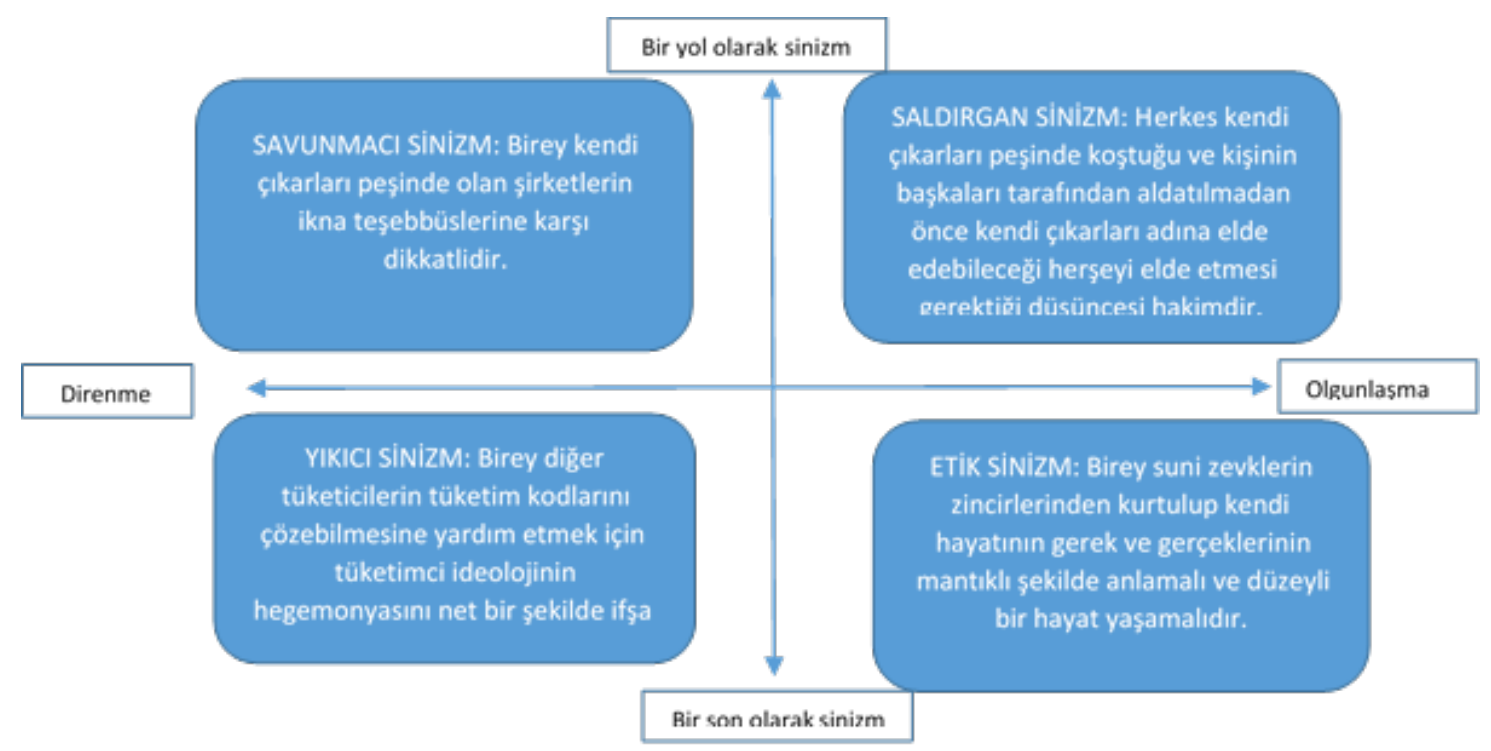

\section{Şekil 1.Tüketici Sinizminin Dört Tipi}

Kaynak: Odou ve Pechpeyrou, 2011:1802

Tüketimde sinizm olgusunun ve tüketicilerde bu tür eğilimlerin varlığını destekleyebilecek farklı konulardaki çalışmalar da tüketicilerin sinik hissedebildiklerini göstermektedir. Örneğin, tüketici yabancılaşması kavramı, tüketicilerin işletmeye yönelik güvensizlik ve firma çıkarları için feda edilme hislerine dair tutumları bir arada ele almaktadır (Allison, 1978:566). Bunun yanında, araştırmacılar reklam mesajlarına yönelik önemli düzeyde bir tüketici şüpheciliği bulgusuna da ulaşmışlardır (Koslow, 2000:265). Bu bulgu sinizmin inanç bileşeni ile ilgilenmekte ancak sinizmde var olan çıkarlar için kullanılma ve negatif duygu algısını içine almamaktadır (Helm, 2004:345).

\subsection{Tüketici Sinizminin Sebepleri}

Sinizm bir tutum olması itibarıyla bu tutumun oluşumunda birçok faktör etkili olabilmektedir. $\mathrm{Bu}$ faktörlerin doğru anlaşılması sinizmin tespiti ve üstesinden gelinebilmesi açısından önemli bir konudur. Bu sebeplerin ortaya konulmasının tüketici marka ilişkilerindeki sorunların çözümüne de doğrudan katkı sağlayacağ 1 değerlendirilmektedir.

Tüketici sinizmi öğrenilen ve süreklilik gösterebilen bir tutumdur. Bu bağlamda sinik tutumların ortaya çıkmasından önceki tecrübeler önemli hale gelmektedir. Helm (2006:4) sinik tüketicilerin sinik olmadıkları dönemi hatırlayabildiklerini ve sinik hale gelmelerine yol açan özel olayları anlatabildiklerini söylemektedir. Buna karşılık, ortalama bir şüphecilik özelliği taşıyan tüketiciler, doğal bir olgunlaşma sürecinin bir parçası olarak yavaş yavaş olgunlaşması deneyimini yaşamaktadırlar. Sinik tüketicilerin tanımladığı kritik olaylar sinizm yapısının temel elementleri olan hayal kırıklıkları sonrası bilinçlenme ve çıkarlar için kullanılma algısını yansıtmaktadır.

Literatürde yaygın kabul gören bu görüş, tüketici-marka ilişkileri sürecinde yaşananların ve sonucunda edinilmiş tecrübelerin tüketicileri olgunlaştırdığ ettiği ve markaya yönelik tutumları şekillendirdiğini ortaya koymaktadır. Tüketicilerin piyasada edindikleri olumsuz tecrübelerin markaların kendi çıkarları için aldatmalara başvurabildikleri algısına ve bunun da sinik davranış eğilimlerine yol açtı̆̆ söylenebilecektir. 
Beklentiler ve bu beklentilerin karşılanma düzeyleri de tüketicilerde sinik tutumların belirleyicisi olabilmektedir. Bu tür karşılanmamış beklentilerin tüketicilerde bir genellemeye yol açabildiği ve sıklıkla negatif sonuçlara maruz kalmalarının geleceğe dair de bir tatminsizlik beklentisine sebep olabildiği kabul edilmektedir. $\mathrm{Bu}$ tür tüketiciler çevresel mesajlara daha duyarlı hale gelmekte (Summer ve Granbois, 1977:155) ve piyasadaki bir firma tarafından verilen mesajlara yönelik tepkiler ortaya koyabilmektedir (Chu ve Chylinsky, 2006:3).

Forehand ve Grier (2003:350) sadece beklentilerin değil aynı zamanda tüketici prensipleriyle ilgili değerlerin karşılanmadığı takdirde tüketicilerde şüphelerin oluşabildiğini savunmaktadır. Tüketiciyle hizmet sağlayıcı arasındaki etik standartlarda bir farklılık oluştuğunda, tüketici hizmet sağlayıcıyı değiştirebilmekte ya da şikayet davranış1 sergileyebilmektedir (Alexander, 2002:223). Bu sebeple de tüketiciler kendi değer ve prensipleri çiğnendiğinde de şüphecilik eğilimi sergileyebilmekte ve bu da sinik tutumların şiddetinde belirleyici olabilmektedir. Bu noktada şüphecilik ve sinizm ayrımının da doğru yapılması gerekmektedir. Mohr ve arkadaşları (1998) pazarlama literatüründe iyi bilinen şüphecilik (scepticism) kavramı ile sinizm kavramını arasındaki farka da değinmektedirler. $\mathrm{Bu}$ araştırmacılar, şüpheciliğin duruma özel bir kavram olduğundan, sinizmin ise daha derin temelleri olduğundan bahsetmekte ve Kanter ve Mirvis'den (1989) şu alıntıyı yapmaktadırlar: 'Şüphecilik (scepticism) spesifik bir konu hakkında şüphe duygularını ifade ederken, sinizm sadece bahsedilen konu hakkında değil aynı zamanda bu konudan bahsetmenin altında yatan sebeplere dair derin şüpheleri de kapsamaktadır. Aynı araştırmacılar şüphecilikte bilgi arttıkça şüpheciliğin azalabildiğini ama sinizmde tutumun değişmesinin çok zor olduğunu da dile getirmektedirler (Mohr vd, 1998:34).

Tüketici sinizmi konusunda önemli çalışmaları olan Chu ve Chylinski(2006:3) yaptıkları bir çalışmada, tüketici sinizmi sebeplerine dair dinamik bir model ortaya koymuşlardır. Bu modele göre, tüketicilerin firmayla ilişkilerinde amaç ve değerleri bağlamında bir değerlendirme yaptıkları görülmektedir. Tüketicilerin amaçları ve karşılaştıkları sonuçlar arasında ortaya çıkan bir uyuşmazlık ile yine kendi değerleri ve firma değerlerine yönelik algıları arasındaki uyuşmazlık olumsuz bir yanılma duygusuna ve tatminsizliğe yol açmaktadır. Bu yanılma ve tatminsizlik bir sebep-sonuç döngüsü şeklinde ele alınmaktadır. $\mathrm{Bu}$ döngüsel süreç tüketici sinizmi ile sonuçlanmaktadır. Şekil 2'de verilen bu modele göre, tüketici sinizmi zaman içerisinde gelişmekte ve şiddetlenmektedir. Araştırmacılar tüketici sinizminin markaya karşı dikkatli davranma tepkisiyle başlayan bu sürecin, sonrasında sırasıyla şikayet, negatif ağızdan ağıza pazarlama, markayı terk etme ve en şiddetli haliyle intikam davranışları sergileme şeklinde bir seyir izlediğine dikkat çekmektedir. 


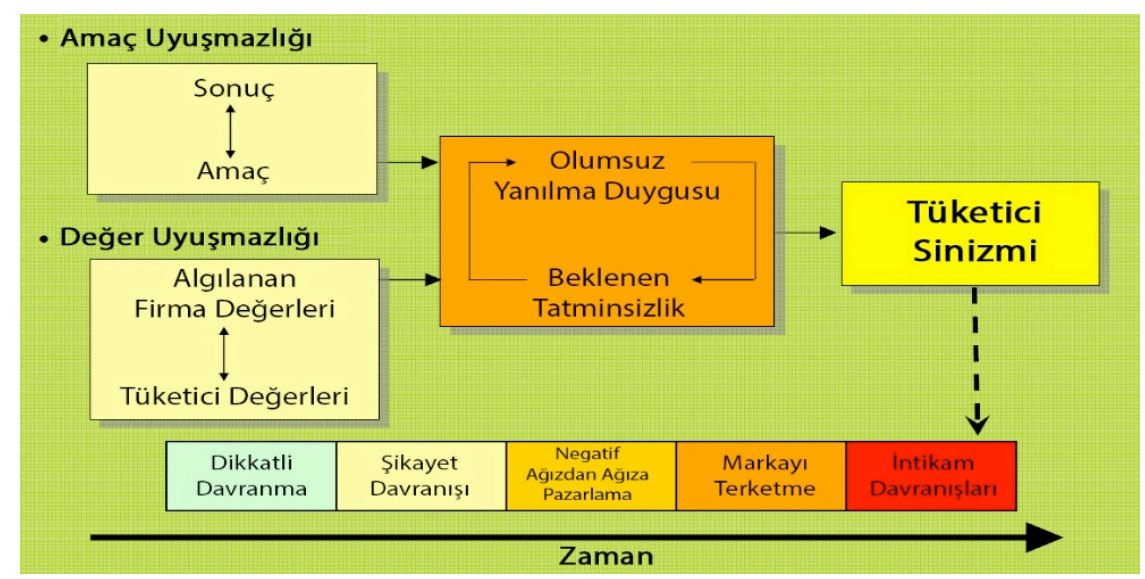

Şekil 2. Tüketici Sinizminin Dinamik Modeli

Kaynak: Chu ve Chylinski, 2010:3

Öte yandan, doğrudan bir satın alma tecrübesi olmadan da politika, ekonomi ve tüketim alanlarında yerine getirilmemiş sözlerin yarattığı hayal kırıklıkları da her türlü iyi niyetli ya da özverili olduğu düşünülen duruma karşı toplu bir güvensizliği beraberinde getirmektedir. Çünkü hemen hemen tüm bireylerin dilin yanıltma ya da aldatma eğiliminin farkında olmaları, tüm formlarıyla reklamcılara, medyaya ve otoriteye karşı şüphe duyulmasına yol açmaktadır. Pollay (1986:29) bunlar arasından tüketimle yakın ilgisinden dolayı özellikle reklamın tüketici sinizmi üzerindeki etkisine dikkat çekmekte ve kitlesel iletişimler yoluyla yapılan reklamların tüm toplumu sinik hale getirebildiğini belirtmektedir. Pollay'ın bu konudaki görüşlerini açıklarken temel aldığı sözler dikkat çekicidir;

Birçok sosyal eleştirmene göre reklam, başart güdülerini ve taklitçilik takıntılarını kullanarak, cazibeyi maksimize ederken, bilgilendirmeyi mimimize ederek, objektif düşünceleri önemsizleştirerek, mantıksız durumları bir şekilde mantığa bürüyerek, genellikle de erkek, kadın ya da çocukları irrasyonel tüketici rolüne indirgeyerek tüketimin materyalist değerlerini güçlendirme felsefesiyle yakından ilişkili bir kavramdır (Sean MacBride 1980'den akt. Pollay, 1986:29).

Pollay'in bu ifadeleri reklamın tüketicilere bakış açısını ve bu bakış açısındaki problemi net bir şekilde ortaya koymaktadır. Günümüz tüketicisinin eskiye göre çok daha bilinçli ve sorgulayıcı olduğu göz önüne alındığında reklamların tüketici gözündeki güvenilirlik düzeyi konusunda sıkıntılar olduğu söylenebilecektir. Tüketicilerin reklamlara karşı hissedecekleri bir güvensizliğin sinik tutumların oluşumunda tetikleyici bir rol üstlenebileceği de değerlendirilmelidir.

Tüketim ve tüketici davranışlarının marka ve müşteriyi yönlendirebilmesi bağlamında medya ve izleyicileri ele alan çalışmasında Brants (2013:16) da tüketicilerde medyaya duyulan güvenin giderek azaldığını ve sinizmin ise her geçen gün arttığını ifade etmektedir. Araştırmacı bu bağlamda medyanın sinik tüketicilerin artmaması ve habercilik mesleğinin geleceği için tedbirler alınması gerektiğinden bahsetmektedir. 
Reklamın mesajları abartılı şekilde aktaran bir araç olduğuna dair inanış sadece araştırmacılara değil aynı zamanda tüketicilere kadar da uzanmaktadır. Bu konuda Pollay, 'hemen hemen tüm bireylerin reklam dilindeki bu yanıltıcılığın farkında olmalarından dolayı, reklamlar aslında bireyleri toplum olarak bir sinikler topluluğuna dönüştürmekte ve tüm toplumu reklamcılar, medya ve de yetkililer hakkında şüphe duyar hale getirmektedir' ifadelerini kullanmaktadır. Pollay aynı zamanda 'Bizler kendimizi kişisel olarak da reklamın yönlendiriciliğine bağımlı görmeyi seviyoruz. Reklam, neredeyse tamamı ona bağımlı hale geldiğini hisseden siniklere rağmen başarılı bir şekilde etkisini gösterebilmektedir' ifadesini kullanmaktadır (Pollay, 1986:29). Özellikle de reklamlar ve medyanın bu yanıltıcılığından kaynaklanan tüketicilerin piyasa geneline karşı sahip oldukları güvensizlik tutumlar, yaşanan tecrübelerde payı olmayan diğer genel ya da yerel ürünlerin tercihlerinde de olumsuz etkilere sebep olabilmektedir (Alpert, 1993:62).

Toplumsal sinizmin yükselmekte olup olmadığı ve bundan nelerin sorumlu görülebileceği soruları net şekilde cevaplanabilecek sorular değildir. Tüketim kültürü ve pazarlama taktikleri bazı sosyal eleştirmenler için sinizmin günah keçileri olabilirler. Ancak pazarlama taktikleri ve sinizm yapısı içindeki faktörler arasındaki ilişkiler çok güçlü olmasından dolayı sinik tutumlar piyasadaki markalar, kampanyalar ya da reklamlar gibi piyasa faktörlerine yönelik tepkilere de yol açabilecektir (Helm, 2006:18).

Öte yandan, Pollay'ın (1986:19) ifadeleri açısından bakıldığında sinizm sadece mesajlar yoluyla ikna teşebbüslerine karşı değil aynı zamanda markaların niyet ve amaçlarına yönelik olarak da bir psikolojik savunma aracı olarak işlev göstermektedir. Psikolojik bir araç olarak, bu tür sinizm, pazarlama tekniklerine karşı koymak için kullanılmakta ve sadece tüketim ideolojisine değil aynı zamanda genele yönelik bir şüphe ile ilişkili görülmektedir. Ancak tüketici sinizminin bu savunmacı doğası sorgulanabilir. Aynen hedeflerine ulaşmak için ahlaki prensipleri bir tarafa bırakan pazarlamacılar gibi tüketiciler de sistemi hatta diğer tüketicileri kötüye kullanarak aynı şeyi yapabilmektedirler (Kretz, 2010'dan akt. Odou ve Pechpeyrou, 2011:1799).

Ancak tüketici sinizmi sadece bu psikolojik perspektife indirgenmemelidir. Sinizmin temelindeki görülen inanışlar tüketicilerin içinde yaşadıkları hayatı kontrol edebilmelerine imkan vermektedir. Gerçekten de sinizm güçlü bir eleştirel araçtır ve tüketicilere pazarlamanın gizli yüzünü ortaya çıkarma, ikna girişimlerinin arkasındaki çıkar kavgalarını görebilme ve tüketim toplumunun dayatmalarını fark etme imkanı vermektedir (Cherrier ve Murray, 2004:512). Bu açıdan tüketici sinizmi sadece psikolojik bir savunma aracı olarak değil, aynı zamanda daha küresel bir tüketim karşıtlığı eğiliminin bir parçası olarak görülmelidir (Dobscha ve Ozanne, 2001:212).

Tüketici sinizminin sebepleri olarak konusunda çok daha radikal bakış açıları olduğunu ifade eden Thompson ve Arsel (2004:637) de Starbucks üzerine yaptıkları çalışmada makyavelist pazarlama sistemi tarafindan sömürüldüklerini düşünen bir karşıt görüş grubunu anlatmaktadır. Çalışmada bu insanlar yerel kafeleri tercih etmelerinin altında yatan asıl sebep olarak, küresel kapitalizmin aldatıcılığının farkında olmalarını göstermektedirler. Bu ifade tüketicilerdeki sinik eğilimlerin temelinde yatan aşırı çıkarcılık ve firsatçılık algısını da destekler niteliktedir. 
Tüm bu sebeplerin hem kısaca özetlenmesi hem de maddeler halinde görülebilmesini sağlayabilme adına, tüketicilerde sinik eğilimler oluşmasına yol açabilen sebepler konusunda aşağıdaki gibi bir sıralama yapılması yararlı olacaktır;

1. Olumsuz Tüketim deneyimleri

2. Firma tarafindan kullanılma algisı

3. Karşılanmamış Beklentiler

4. Karşılanmamış değer ve prensipler

5. Reklam mesajlarının aldatıcılığı

6. Savunma mekanizması geliştirme ihtiyacı

7. Yaşamı kontrol edebilme isteği

8. Makyavelist pazarlama sistemine tepki

\subsection{Tüketici Sinizminin Sonuçları}

Markaların marka bağlılı̆̆ı ve sadakati yaratmak için büyük maliyetlere katlanmayı göze almaktan çekinmedikleri günümüz piyasalarında markaya duyulacak güven, 'olsa iyi olur' mantığıyla değil şirketler için hayati derecede kritik bir stratejik varlık olarak değerlendirilmelidir (Chatterjee ve Chaudhuri, 2005:12).

Markaya olan güvenini kaybetmiş sinik bireyler ve özellikle davranışa dökülmüş sinik eğilimler markalar için son derece tehlikeli olabilecektir. Markaya karşı güvenini kaybetmiş, aldatıldığını ya da marka çıkarları için feda edildiğini düşünen diğer bir deyişle sinik hale gelmiş tüketicilerin firmaya verebilecekleri zarar günümüz internet çağında çok daha yıkıcı olabilecektir. Marka ile ilişkilerinde tatminsizlik yaşayan tüketiciler tutum temelinde bakıldığında üç farklı boyutta tepki ortaya koyabileceklerdir. Bu tepki kimi zaman duygusal, kimi zaman bilişsel kimi zaman da davranışsal şekilde kendini gösterebilmektedir.

Tüketicilerin sürekli iç içe oldukları tüketim süreçlerinde edindikleri tecrübeler ve özellikle de beklentilerini karşılamayan tecrübeler birçok tüketicide sadece duygusal boyutta bir tepki olarak kendini göstermektedir. Bu açıdan, tüketicilerin ilk tatminsizlik sonrası yaşanan hayal kırıklıkları ve sonucunda firma ya da markaya karşı hissettiği olumsuz duygular tüketici sinizminin duygusal boyutunu ifade edebilecektir. Birçok çalışma, pek çok tatmin olmamış müşterinin şikayet davranışına başvurmadığını göstermektedir. Duygusal boyut düzeyinde kalmış ve inanç ve davranışa dökülmemiş sinizm tutumlarının marka açısından çok tehlikeli olmayabileceği algısı olsa da, bu boyuttaki birikimlerin inanış ve davranış boyutlarına uzanmaması için önleyici tedbirlere ihtiyaç duyulmaktadır. Bu noktada önemli olan firmaların küçük olumsuzlukları göz ardı etmemeleri ve zamanında müdahale edebilme refleksini gösterebilmeleridir.

Tüketici sinizminin bilişsel boyutunu ise, tatminsizlik tecrübelerinin artması sonucunda tüketici zihninde oluşan, firma ya da markanın güvenilmez ya da çıkarcı olduğuna ve tüketiciyi kötüye kullanmaktan kaçınmayacağına dair kanaat oluşturmaktadır. Çünkü tüketici hayal kırıklığı yaşamış ve hakları korunmaya değer görülmemiştir (Bougie vd., 2003:389). Bazıları için firmanın kendi çıkarlarının peşinde olduğu fikri sadece bir şüphe değil, artık bir inanç haline gelmiştir ve inanç sonrasında 
sinik tüketici markayı terk edebilmektedir (Kanter ve Mirvis 1989'den akt. Chu ve Chylinsky, 2006:2). Sadece şüphe olarak tüketici zihninde yer alan bazı düşüncelerin inanç haline gelmesi, oluşabilecek zararın potansiyelini de bir anda artırabilecektir. Tüketici zihninde markaya yönelik olarak oluşan ve inanç şeklinde sabitlenen duygu ve düşünceler artık marka için boyutu kestirilemeyecek potansiyel bir tehlike olarak değerlendirilebilecektir. Özellikle de az sayıda tüketicide başlayan bu tür inançların bir domino etkisiyle çok geniş müşteri kitlelerine ulaşabileceği değerlendirildiğinde tüketici sinizminin yıkıcı potansiyeli daha iyi değerlendirilebilecektir.

Tüketiciler özellikle de tatminsizliklerinin suçlusu olarak firmanın kendi çıkarları peşinde olmasını gördüklerinde, belirli ve öngörülebilir bir takım davranışlarla da tepkilerini göstermektedirler. Sinizmin marka ya da firma açısından belki de en tehlikeli boyutu olan bu davranışsal boyut çok farklı davranışsal tepkiler şeklinde ortaya çıkabilmektedir. $\mathrm{Bu}$ tepkiler, satın alma sonrası risklerden korunabilmek için tüketicilerin geliştirdikleri mücadele stratejilerinde gözlemlenebilen 'dikkatli satın alma' davranışı şeklinde olabileceği gibi, firma ya da markayı cezalandırmayı amaçlayan tepki davranışları şeklinde de görülebilecektir. Bu konudaki davranışsal tepkilerin artmasının temelinde sinizmdeki artışın olduğunu ifade edilebilecektir (Chu ve Chylinsky, 2006:1). Tatmin olmamış ya da tatminsizliği telafi edilmeye gerek duyulmamış tüketiciler en basit davranışlarla tepki verebilecekleri gibi aşırı sayılabilecek tepkilerle de bu tatminsizlikleri kendi açılarından telafi etme yoluna başvurabileceklerdir. Bunun en 1lımlı ve yaygın yollarından birisi olarak online tüketici gruplarına katılmak ve tatminsizliklerini diğer insanlarla paylaşmak gösterilebilecektir (Bailey, 2005:66).

Tüketici tepki davranışları konusunda dikkatli davranma, şikayet, negatif wom, ayrılma ve intikam gibi tepkiler literatürde araştırılmış ve sinizmin hiyerarşik etkisini de ortaya koymuştur. Bu etkiler firma ya da tüketiciler için potansiyel olarak önemli olmasından dolayı üzerinde daha fazla çalışılmayı gerektirmektedir (Forehand ve Grier, 2003:349). Rekabetçi piyasada firma ve tüketici arasındaki ilişki her zaman için belirsizdir. Sinizmin gücü arttıç̧a, tüketicinin firmaya bağlı kalması ihtimali azaltmakta ve bu da karşı tepkilere yol açabilmektedir. Bu tür sinik tepkiler firma için zarar verici olabilirken, bir taraftan da tüketicilerin genel huzurlarını bozabilmektedir (Chu ve Chylinsky, 2006:2). Özellikle sosyal medyanın ve sanal ağların böylesine yaygın ve etkili şekilde kullanıldığı günümüz teknoloji dünyasında, marka ya da firmanın cezalandırılması amacıyla yola çıkıldığında, bu cezanın boyutunun bir süre sonra şikayet davranışı sergileyen tüketicinin de kontrolünden çıkabileceği de açıktır. Piyasadaki tüketici davranışlarının eskisi gibi marka tarafından kontrol altına alınamadığı unutulmamalı ve buna yol açabilecek tutumların önüne geçilecek çabalar sergilenmelidir.

Daha şiddetli tepkilerde, tüketici isyanı geleneksel tüketici şikayetinin ötesine geçen bir tür telafi yöntemidir. Yıkıcı ve hatta şiddetli protestolar şeklinde görülebilen bu tepkiler (Lacayo, 1999:25), aslında pazarlama uygulamalarındaki etik dış1 davranışları düzeltme isteğini yansıtmakta ve kimi zaman bu istek yeni ürünler yerine ikinci el ürün alma şeklinde de kendini gösterebilmektedir (Dobscha ve Ozanne, 1998:95). Bu davranış aynı zamanda pazarlama ya da piyasa güçlerinin amaçları doğrultusunda yapılan aldatmacalara da bir tepkidir (Chu ve Chylinsky, 2006:2). Tüketim karşıtı tutumlar üzerine yapılan bazı araştırmalar da bazı tüketicilerin reklam 
mesajlarını tahrif etmeye kadar uzanabilen tepkiler gösterdiklerini ortaya koymaktadır (Helm, 2004:345).

Tüketici araştırmaları küresel hedefli kötüleyici davranışların yanında, sadece belirli şirketlere yönelik negatif ya da güvensiz tutumları da ele almışlardır. Örneğin Aron, intikam duygusu içindeki bazı tüketicilerin misillemelerine dair farklı formlarda davranışlar tanımlamaktadır. Bunlar online tepki toplulukları, boykot etme, tehdit, davalar ve diğer tüketicileri olumsuz etkileme şeklinde kendini gösterebilmektedir. Bu davranışlar kimi zaman da vandalizm, negatif wom, formal şikayetler şeklinde görülebilmektedir (Aron, 2001:115).

Helm yaptığı araştırmada sinik tüketicilerin davranışlarının diğer alanlardaki sinik bireylerden farklılıklar gösterdiği sonucuna ulaşmıştır. Politika gibi diğer alanlardaki sinizmle tipik şekilde ilişkili davranışlar sergileyen sinik tüketiciler eleştirme ve kendini çekme davranışları sergilemektedirler. Aynı zamanda, sinik tüketiciler tüketim bağlamındaki risk yönetimi çabaları (tüketici raporlarını incelemek vb) ve sosyal sorumluluk duygusuyla ortaya çıkan davranışlarla da ilgililerdir. Bu davranışların her ikisi de güvenilir marka ve işletmelerle güçlü bir işbirliği oluşmasını da kapsamaktadır. Her ne kadar başlangiçtaki beklenti sinik tüketicilerin daha az sadakat gösterecekleri şeklinde olsa da, yapılan görüşmeler sinik tüketicilerin daha az sinik özellik taşıyan diğer bireylerden daha istekli bir bağl1lık sergilediklerini göstermiştir (Helm, 2006:14).

$\mathrm{Bu}$ sonuçların daha sonra yapılan bir diğer çalışma olan Devlin ve McKechnie'nin (2008) çalışmasında da doğrulandığı görülmektedir. Bu araştırmacılar finans sektöründe faaliyet gösteren firmalar ve müşterileri ile odak görüşmeler gerçekleştirmiş ve finans sektöründe sinizm eğiliminin yoğun yaşandığına dikkat çekmişlerdir. Araştırmacılar yaptıkları görüşmelerde müşterilerin 'onlar kendi çıkarlarını düşünürken ben neden onlara sadık kalayım mantığıyla hareket ettiklerini' dile getirmektedir (Devlin ve McKechnie, 2008:660).

Tüketici sinizmi kavramı bağlılık konusunda bir avantaj sağlayabilmesinin yanında, tüketici tatminsizliğinin farklı şekillerde ifade edilmesi konusunda da psikolojik birtakım açıklamalar ortaya koyarak konuya katkı sunmaktadır. Bir grup sinizm literatürü davranışsal sonuçları kategorize ederek iki ana tip davranışsal sonuca dikkat çekmektedir; Vazgeçme davranışları ve kötüleme davranışları (Helm, 2006:18).

Vazgeçme tarzı sinik tutumlar konusunda sunulan, 'Sade yaşam' terimi birçok farklı yaşam tarzını ve motivasyonu kapsamakta ve bunların birçoğu piyasaya karşı bir isyan duygusundan ziyade etik tercihlerle daha yakından ilgili görülmektedir. Sade yaşam felsefesi mümkün olduğu kadar tüketimden uzak durmaya çalışma odaklı bir felsefe olarak dikkat çekmektedir. Dobscha ve Ozanne (1998) görüştüğü sade yaşamcı tüketicilerin kısmen de olsa piyasa uygulamalarına karşı derin bir şüphecilik sebebiyle bu davranışı sergilediklerini ifade etmektedir. Zavestoski de bu tarz bir yaşamı tercih edenlerin bir süre tüketim amaçlı zenginlik peşinde koştuklarını ve sonrasında yaşadıkları hayal kırıklıklarından dolayı bu yaşam tarzını tercih ettiklerini söylemektedir (Zavestoski, 2002:151). Bir tür köklü değişim anlamına gelen bu tepkiler her ne kadar modern dünyada çok zor görünse de, markaların etik dışı davranışları konusunda farkındalık yaratma adına oldukça etkili olabilmektedir.

Kötüleme davranışları konusunda ise, son dönemlerde yapılan tüketici araştırmaları kötüleme türü davranışların bazı örneklerini ele almışlardır. $\mathrm{Bu}$ tür 
davranışlar negatif wom şeklinde kimi zaman yüz yüze kimi zaman da e-wom tarzında online ortamlarda olabilmektedir (Güven, 2013). Bu tür davranışlar bazen negatif wom un da ötesine geçerek bir tüketici hareketine dönüşebilmektedir. Örneğin, piyasaya, özellikle de büyük işletmelere ve tüketicinin pasif rolüne karşı isyan, Burning Man adlı aktivism hareketindeki ana temadır. Bu hareketin katılımcıları marka ismi ve logolarını kapatmakta, aynı zamanda işletmeleri ve tüketicileri aşağılama davranışı sergilemektedirler (Kozinets, 2002,s.28).

Yine tüketimcilik ve reklam üzerine eleştirel görüşleriyle bilinen bir yayın olan reklam avcıları (adbusters) dergisi 'kültür karışıklığını' ya da birtakım isyan yöntemlerini teşvik etmektedir. Buradan hareketle bu iki grubun üyelerinin sinik tüketiciler grubunda ele alınması son derece doğal olacaktır. Güven duygusuna dair ihanet algısı sinik tüketicilerin kimi zaman aşırı uçlarda seyreden bu gibi davranışsal tepkilerinin temelidir. Bu bireyler örneğin bir web sitesi aracılığıyla şikayetlerini kitlelere ulaştırabilmekte ve böylece bir sinizm kültürü yaratabilmektedirler. Tüketiciler tarafindan yaratılan bu websiteleri hem bir misilleme ya da intikam araci olmakta hem de tüm tüketiciler için piyasayı daha etik bir noktaya getirme çabalarına destek olmaktadır (Helm, 2006:19). Bu tür toplu hareketlerin bireysel tepkilerden çok daha yıkıcı olabileceği unutulmamalı ve bu tür hareketlere dönüşme potansiyeli gösteren kötüleme davranışlarına çok daha hızlı müdahale edilebilmesi gerekmektedir. Tüm bu çabaların ise marka ya da işletmeye fazladan maliyet getireceği açıktır.

Tüketici sinizmine dair olumlu bir bakış açısı getiren ve bu tutumun tüketicileri bilinçlenme ve farkındalığa hazırladığını dile getiren, Odou ve Pechpeyrou (2011:1805) da yaptıkları çalışmada tüketici sinizmi kavramını sebeplerden başlayarak sonuçlarına doğru genel bir süreç halinde ifade etmektedirler. Bu çalışmaya göre, tüketiciler tüketim deneyimleri sırasında pek çok defa tatminsizlik duygusu yaşamaktadırlar. Tüketiciler hayal kırıklıkları ve aldatılma hislerine yol açan bu tür satın ama deneyimleri sonrasında manipüle edildiklerinin ve firmalar tarafindan sürekli şekilde abartılı ikna çabalarına maruz bırakıldıklarının farkına varmaktadırlar. Yaşanılan bu olumsuz tüketim deneyimleri ve farkındalık tüketicilerde iki tür bilinçlenmeye yol açabilmektedir. Birinci tür bilinçlenme olan tüketime karşı bilinçlenmede, tüketiciler pazarlamacıları sahte söylemler üreten kaynaklar olarak görmekte ve sonrasında da pazarlama tekniklerine karşı bir direniş geliştirmektedirler. Pazarlama tekniklerine karşı sergilenen bu direniş, savunmacı ya da saldırgan sinizm şeklinde kendini gösterebilmektedir. Savunmacı tarz sinizm davranışı sergileyen tüketiciler, firmaların tamamen kendi çıkarlarının peşinde olduklarını, bu sebeple de onların ikna teşebbüslerinden korunulması gerektiği inancı taşımaktadırlar. Saldırgan sinizm türü davranışta ise piyasadaki herkesin kendi çıkarlarını düşündüğü ve aldatılmadan önce elde edebileceğiniz herşeyi elde etmek gerektiği düşüncesi hakimdir. Kişinin yaşam bilincine ulaşması şeklinde karşımıza çıkan diğer bilinçlenme türünde ise, pazarlamacıların bir suni ihtiyaçlar üreticisi olarak kabul edilmesi ve tüketim yoluyla mutluluk elde etme çabalarına karşı bir bilinçlenme söz konusudur. $\mathrm{Bu}$ tür bilinçlenmede tüketimci ideolojiye karşı bir direniş dikkat çekmektedir. Bu direniş ise yıkıcı ve etik sinizm şeklinde kendini göstermektedir. Yıkıcı tür sinizm davranışında bir aktivist mantığıyla diğer tüketicilerin piyasadaki tüketim kodlarını çözmelerine yardımcı olunmakta ve tüketimci ideoloji güçlü bir şekilde eleştirilmektedir. Etik tür sinizm davranışında ise bireyin bir anlamda özgürleşmesi ve grup hareketlerinden sıyrılarak suni ihtiyaç ve zevklerden kendini kurtarması ve değerlendirme kriteri olarak da sadece kendi yargılarını kabul etmesi sözkonusudur. 
Bahsedilen bu bilinçlenme türlerinden ilkinde bilinçlenme konusunun mikro düzeyde marka ya da ürünler konusuna odaklandığı diğerinde ise daha genel bir bilinçlenme yoluyla bir hayat görüşü ortaya çıktığını söylemek mümkün olabilecektir. Her ne kadar her iki tür bilinçlenme de markalar açısından bir risk doğursa da, özellikle tüketime karşı bilinçlenmenin marka ve ürün açısından daha hızlı kendini gösterebilecek bir risk taşıdı̆̆ 1 değerlendirilmektedir. Yaşam bilinci konusu ise artık marka ve ürün vurgusu yapmaması ve bir yaşam felsefesi yaratması sebebiyle daha sosyoloji temelli bir durum ortaya koymaktadır.

Farklı çalışmalarda farklı yönlerine değinilen bu sonuçların aşağıdaki gibi maddelenmesi tüketici sinizminin sonuçlarının daha net görülebilmesine yardımcı olacaktır;

1. Markaya karşı soğukluk

2. Dikkatli Satın Alma Davranışı

3. Markayı terk etme

4. Negatif wom

5. Boykot grupları ve Tüketici sitelerine üyelikler

6. Şiddetli protestolar

7. Reklam tahrifleri-Vandalizm

8. Bilinçlenme ve Sorgulama

\section{Sonuç ve Öneriler}

Şirketlerin dürüstlükten yoksun olduğu inancı ve belirli markalardan kaçınma gibi negatif duygularla karakterize edilebilen tüketici sinizmi kavramı, bir tutum olması itibarıyla, tüm diğer tutumlar gibi geçmiş yaşantılar ve edinilen tecrübelerin doğal bir sonucu olarak karşımıza çıkmaktadır. Kimi zaman basit bir tatminsizlikle ilk adımları atılan, kimi zaman da marka ile yaşanılan olumsuz bir deneyimle pekiştirilebilen tüketici sinizminin reklam mesajlarından (Pollay, 1986) ve diğer tüketicilerin yorumlarından (Kozinets, 2002:25) da etkilenebildiği görülmektedir.

Marka ya da firmaya güven kaybıyla sonuçlanan tüketici sinizmi, çoğu zaman sadece bu güven kaybıyla kalmamakta, çok daha farklı boyutlarda davranışa dökülebilmektedir. Yaşanılan tatminsizliklerin başkalarına anlatılmasından, reklam mesajlarının tahrif edilmesine (Helm, 2004:19) oradan toplu boykotlara kadar uzanabilen sonuçlara sahip olabilmektedir (Aron, 2001:115).

Günümüzde bilginin 1şık hızıyla yayıldığı göz önüne alındığında, sinik bireylerin marka ya da firmaya verebilecekleri zararın boyutları çok büyük olabilecektir. Bu bağlamda tutundurma ve müşteri bağlılığ gibi hayati konularda hiçbir masraftan kaçınmayan firmaların, tüm bu masrafları boşa çıkarabilme potansiyeline sahip tüketici sinizminin farkında olmaları gerekmektedir. Konunun içeriği ve boyutlarının doğru analiz edilmesi, tüketicilerde oluşan bu olumsuz tutumun daha ilk evrelerinde tespit edilmesi ve davranışa dökülmesini engelleyebilecektir.

$\mathrm{Bu}$ bağlamda, sinizmin sebepleri arasında değerlendirilen olumsuz tecrübeler ve tatminsizlikler probleminin çözümü öncelikle tüketiciyle yakın bir diyalogu gerektirmektedir. Tüketiciyle kurulması gereken bu yakın diyalog ve iletişimin en 
önemli ayaklarından birisi çalışanlardır. İşletmelerin yaşanacak olumsuzlukların ortaya çıkardığı sorunlar konusunda bilgili olması, gerek vereceği tepkiler konusunda gerekse de güven sağlama noktasında son derece önemli görülmektedir. Çalışanların tüketici davranışları konusunda eğitilmeleri firmanın geleceğe daha güvenle bakmasını sağlayabilecektir.

Öte yandan, tüketici sinizminin sebepleri arasında görülen reklam iletişimindeki aldatıcılık konusu da firmaların üzerinde dikkatle durmaları gereken bir diğer konu olarak dikkat çekmektedir. İşletmeler reklam mesajlarının içeriğini hazırlarken tek ve yeter amaç olarak tüketiciyi etkilemeyi görmemeli, bu etkiyi uyandırmaya çalışırken yanıltıcı ya da aldatıcı içeriğin uzun vadede markaya yönelik olumsuz getirileri olabileceğini de değerlendirmelidirler. Reklamlar konusunda tüketicilerin görüş ve yorumlarının alınması da güven verme konusunda etkili bir adım olabilecektir. Zira reklamda aldatıldığı hissine kapılan bir tüketici firmaya düşüncelerini iletebildiği takdirde, reklamın amacı konusunda olumsuz düşüncelere girmekten ve sonucunda sinik bir tüketici haline gelmekten kurtarılabilecektir. En yaygın tüketici sinizmi türünün savunmacı sinizm olmasından hareketle, firmaların çıkarcı olduklarına ve tüketiciyi ikna teşebbüsleriyle aldatmaya çalıştıklarına dair inanç, firma ya da markaların üzerinde dikkatle durması gereken bir konu olarak ele alınmalıdır. Özellikle reklamlar ve olumsuz deneyimlerle güçlendiği bilinen bu sinizm türü ile mücadele edilirken, tüketiciler çok iyi gözlemlenmeli ve reklamların gerek içeriği gerekse de kullandıkları dil dikkatle hazırlanmalıdır.

Bunun yanında özellikle sinizm eğilimine sahip tüketicilerin önemsenmedikleri ya da haklarının ciddiye alınmadığı şeklindeki düşüncelerinin önüne geçebilme adına, tüketiciye sorunlarını dile getirme imkanı verilmelidir. Bu imkan şikayet mesajları yazabilmenin yanında, müşteri temsilcileriyle doğrudan görüşebilme imkanlarının artırılması şeklinde de zenginleştirilebilmelidir. Gelen şikayet ya da öneriler konusunda tüketiciye mutlak surette bir dönüş yapılması sinizm eğilimli bireyler başta olmak üzere tüm tüketicilerde olumlu izlenimler uyandırabilecektir. İşletmelerin tüketici yorum siteleri, forumlar ya da sosyal medyayla yakından ilgilenen bir ekibinin bulunmasi ve bu ekibin işletme ya da marka hakkında paylaşılan olumlu ya da olumsuz tüm mesajları dikkatle analiz etmesi ve sonuçları düzenli raporlar halinde yönetime bildirmesi de faydalı olacaktır.

Tüketicilerin tatminsizliklerine vaktinde cevap verebilen, onlarla bir güven ilişkisi kurmayı başarabilen firmalar sinik düşmanlar olarak tabir edilen bir potansiyel düşmanı sadık bir firma dostu haline getirebilecektir. Özetle burada en temel konunun karşılıklı güveni sağlama adına doğru ve etkili bir iletişim sistemi kurmak ve işletmek olduğunu söylemek yararlı olacaktır. Çünkü Odou ve Pechpeyrou (2011) dile getirdiği pazarlama tekniklerine karşı ve tüketim ideolojisine karşı bilinçlenme beraberinde bir tüketici direnişini getirmekte bu tür bir direniş ise markadan başlayarak tüm piyasaya karşı bir tüketim karşıtlığı ile sonuçlanabilecektir. Buradan hareketle firma ve markaların tüketici sinizmi sonucu oluşacak direnişi nötralize edebilecek adımlar atması ve bu adımlarda temel amaç olarak markanın tüketicinin bir çıkar rakibi olmadığı mesajını vurgulaması ve güven oluşturması gerekmektedir.

Tüketici sinizmi konusunu ana hatlarıyla bir çerçeve içine almayı amaçlayan bu çalışmanın ışığında, yapılacak bundan sonraki çalışmalarda farklı sektör ve gruplardaki tüketicilerin tüketici sinizmini ölçebilme adına bir tüketici sinizmi ölçeği geliştirme 
yoluna gidilebilir. Sonrasında ise tüketicilerin sinizm düzeyleri ortaya konularak bu tutumun pazarlamanın farklı konularıyla ilişkileri ele alınabilir. Özellikle reklam mesajları, müşteri temsilcilerinin davranışları ve halkla ilişkiler mesajları gibi konuların tüketici sinizmi üzerindeki etkileri konusunda derinlemesine çalışmalar yapmak yararlı olacaktır.Bu konuda özellikle online ortamlarda artık bir güç haline geldiği net bir şekilde görülebilen e-wom (Güven, 2013) faktörü ve de özellikle negatif e-wom'un tüketici sinizmi ile ilişkisi konusu derinlemesine tahlile ihtiyaç duyan konulardan birisi olarak değerlendirilmektedir.

\section{Kaynakça}

Abraham, R. (2000). 'Organizational cynicism: Bases and consequences', Genetic, social, and general psychology monographs.

Alexander, E. C. (2002). 'Consumer reactions to unethical service recovery', Journal of Business Ethics, 36(3), s.223-237.

Allison, N. K. (1978). 'A psychometric development of a test for consumer alienation from the marketplace', Journal of Marketing Research, s.565-575.

Alpert, F. (1993). Consumer market beliefs and their managerial implications: an empirical examination. Journal of Consumer Marketing, 10(2), 56-70.

Andersson, L. M. (1996). 'Employee cynicism: An examination using a contract violation framework', Human Relations, 49(11), s.1395-1418.

Aron, D. (2001). 'Consumer grudgeholding: Toward a conceptual model and research agenda', Journal Of Consumer Satısfaction Dissatısfaction And Complaining Behavior, 14, s.108-119.

Bailey, A. A. (2005). Consumer awareness and use of product review websites.Journal of Interactive Advertising, 6(1), 68-81.

Bougie, R., Pieters, R., Zeelenberg, M. (2003). 'Angry customers don't come back, they get back: The experience and behavioral implications of anger and dissatisfaction in services', Journal of the Academy of Marketing Science, 31(4), s.377-393.

Brandes, P. M. (1997). 'Organizational cynicism: Its nature, antecedents, and consequences', Doctoral Dissertation, University of Cincinnati.

Brants, K. (2013). Trust, Cynicism and Responsiveness. Rethinking journalism: Trust and participation in a transformed news landscape. London: Routledge, 15-27.

Chatterjee, S.C. Chaudhuri, A., (2005). Are Trusted Brands Important? marketing Management Journal, 15(1), ss.1-16.

Cherrier, H., Murray, J. B. (2004). 'The sociology of consumption: the hidden facet of marketing', Journal of Marketing Management, 20(5-6), s.509-525.

Chowdhury, R. M., Fernando, M. (2014). 'The Relationships of Empathy, Moral Identity and Cynicism with Consumers' Ethical Beliefs: The Mediating Role of Moral Disengagement', Journal of Business Ethics, 124(4), 677-694.

Chu, A., Chylinski, (2006). 'M. A Model of Consumer Cynicism-Antecedents and Consequences', Proceedings of the Australian and New Zealand Marketing Academy.

Chylinski, M., Chu, A.(2010). 'Consumer cynicism: antecedents and consequences'. European Journal of Marketing, 44(6), s.796-837.

Dean, J. W., Brandes, P., Dharwadkar, R. (1998). 'Organizational cynicism', Academy of Management review, 23(2), s. 341-352. 
Dean, J. W., Brandes, P., Dharwadkar, R. (1998). Organizational cynicism.Academy of Management review, 23(2), 341-352.

Delgado-Ballester, E., Luis Munuera-Alemán, J. (2005). Does brand trust matter to brand equity?. Journal of product \& brand management, 14(3), 187-196.

Devlin, J. F., McKechnie, S. (2008). Consumer perceptions of brand architecture in financial services. European Journal of Marketing, 42(5/6), 654-666.

Dobscha, S., Ozanne, J. L. (2001). 'An ecofeminist analysis of environmentally sensitive women using qualitative methodology: The emancipatory potential of an ecological life'. Journal of Public Policy \& Marketing, 20(2), s.201-214.

Dolen, W. M., de Cremer, D., \& de Ruyter, K. (2012). 'Consumer cynicism toward collective buying: the interplay of others' outcomes, social value orientation, and mood', Psychology \& Marketing, 29(5), 306-321.

Forehand, M. R., Grier, S. (2003). 'When is honesty the best policy? The effect of stated company intent on consumer skepticism', Journal of Consumer Psychology, 13(3), s.349-356.

Fuller, B.A.G, (1931). History of Greek Philosophy, Henry Holt, NewYork.

Funder, H. J., Morgan, D., Valizade, S. (2015). Brands\&Consumer Trust Study. Phase I: Desk Research Report.

Gillani, A., Yousafzai, S., Pallister, J. G., Yani-De-Soriano, M. M. (2011). 'Consumer cynicism: an emergent phenomenon in fairtrade?' Presented at: Academy of Marketing Conference 2011: Marketing Fields Forever, Liverpool, UK, 5-7 July.

Güven, E. (2013). 'Sosyal Medyadaki Ağızdan Ağıza Pazarlama Faaliyetlerinin Satın Alma Kararları Üzerine Etkileri', Doktora Tezi, Celal Bayar Üniversitesi Sosyal Bilimler Enstitüsü, Manisa.

Helm, A. (2004). 'Cynics and skeptics: Consumer dispositional trust', Advances in consumer research, 31(1), s.345-351.

Helm, A. E. (2006). 'Cynical consumers: dangerous enemies, loyal friends', Doctoral dissertation, University of Missouri. Columbia.

Hess, J., Story, J. (2005). Trust-based commitment: multidimensional consumer-brand relationships. Journal of Consumer Marketing, 22(6), 313-322.

Kanter, D. L., and Mirvis, P. H. (1989). The cynical Americans: Living and working in an age of discontent and disillusion. San Francisco, CA: Jossey-Bass Inc.

Koslow, S.(2000). 'Can the truth hurt? How honest and persuasive advertising can unintentionally lead to increased consumer skepticism', Journal of consumer Affairs, 34(2), s.245-267.

Kozinets, R. V.(2002). 'The field behind the screen: Using netnography for marketing research in online communities', Journal of marketing research, 39(1), s.61-72.

Lacayo, R. (1999). 'Rage against the machine', Time Magazine, 13, 12.

Laczniak, R. N., DeCarlo, T. E., Ramaswami, S. N.(2001). 'Consumers' responses to negative word-of-mouth communication: An attribution theory perspective'. Journal of consumer Psychology, 11(1), s.57-73.

Mickkonen, I., Moisander, J., Firat, A.F.(2011). Cynical identity projects as consumer resistance - the Scrooge as a social critic?, Consumption Markets \& Culture, 14:1, 99-116, DOI:10.1080/10253866.2011.541163.

Mohr, L. A., Eroğlu, D., Ellen, P. S. (1998). The development and testing of a measure of skepticism toward environmental claims in marketers' communications. Journal of consumer affairs, 32(1), 30-55. 
Odou, P., de Pechpeyrou, P.(2011). ' Consumer cynicism: From resistance to anticonsumption in a disenchanted world?', European Journal of Marketing, 45(11/12), s.1799-1808.

Pollay, Richard W.(1986). "The distorted mirror: Reflections on the unintended consequences of advertising." Journal of Marketing (50), s.18-36.

Roberts, H. G. A. (2006). Dogs' tales: representations of ancient Cynicism in French Renaissance texts (No. 279). Rodopi.

Smith, T. W., Pope, M. K., Sanders, J. D., Allred, K. D., O'Keeffe, J. L.(1988). 'Cynical hostility at home and work: Psychosocial vulnerability across domains', Journal of Research in Personality, 22(4), s.525-548.

Stanley, D. J., Meyer, J. P., Topolnytsky, L. (2005). 'Employee cynicism and resistance to organizational change', Journal of Business and Psychology, 19(4), s.429459.

Summers, J. O., Granbois, D. H. (1977). 'Predictive and normative expectations in consumer dissatisfaction and complaining behavior', Advances in Consumer Research, 4(1), s.155-158.

Thompson, C. J., Arsel, Z. (2004). 'The Starbucks brandscape and consumers' (anticorporate) experiences of glocalization', Journal of Consumer Research, 31(3), s.631-642.

Zavestoski, S.(2002). 'The social-psychological bases of anticonsumption attitudes', Psychology \& Marketing, 19(2), s.149-165. 


\title{
Cynical Attitude in Consumption: The Antecedents and Consequences of Consumer Cynicism
}

\author{
Esra GÜVEN \\ Celal Bayar University \\ Gördes Vocational School \\ Manisa, Turkey \\ esra0505@gmail.com
}

\section{Extensive Summary}

In our modern world where consumer behaviours are essential for the future of the brand, the attitudes in the minds of consumers are getting more and more important. As attitudes are largely resulted from the experiences, consumers can have negative attitudes following the negative experiences with the brands.

Todays's customers experience several consumption every single day and these experiences are causing the customers to develop new attitudes towards the brand or the company itself. When it comes to the consumption experiences of the customers, the negative experiences which will affect the customer trust adversely can be the reasons of damages or loses of the brand in the long run. Trust, one of the important determiners of the realtionship quality between people, is also regarded to have the same effect on the communication between the customer and the brand. It is widely accepted that this relationship must be driven on the basis of trust again. When it is damaged, the potential problems for the brand or the company will be on the way.

Negative experiences and particularly dissatisfactions can be accepted as the most important underlying factors of a newly emerged concept in organizational behaviour : 'consumer cynicism'. According to the common view in marketing literature, the buying experiences between the brand and the customer have an impact on consumer socialization period and shaping the consumer attitudes. The negative experiences, lived in the market, can lead a perception that the companies are always oppurtunist and selfseeker. Such a perception will, as a result, be the reasons of the cynical attitudes for the customers. The most essential studies in the field (Stanley et al., 2005; Andersson, 1996; Dean et al., 1998) are agreed that cynicism is negative attitude which can be both broad and specific in focus, and has cognitive, affective, and behavioural components".

Cynicism is commonly related to suspicion, mistrust, skepticism, and distrust of agent's motives, as well as reactions of dissatisfaction, alienation, and resistance or even hostility towards the agent. Classification of these related constructs according to the cognitive, affective and behavioural components of attitude defines the scope of cynicism represented in the literature. Realizing that company-customer relationship is also in need of tust and when it is broken, the consumer develops a negative attitude toward the product or the company. This negative attitude can be called as 'consumer cynicism'. This study, setting out from the general cynicism concept, deals with a general literature review about a specific kind of cynicism, known as 'consumer cynicism' and aims to put a general frame about the content, the antecedents and the consequences of consumer cynicism. The study also tries to prepare a base review for 
the future research on consumer cynicism which is coming to the fore in the marketing field every other day.

When we talk about cynicism as a negative attitude, we will come across with some underlying reasons. Although the reasons are varied and extensive in the related literature, some of them come to the fore. When viewed from the aspect of Pollay (1986:19), cynicism functions as a defence mechanism not only against the the intention and aims of the brands but against the persuasion attempts of the marketing messages as well. Cynicism, in that way, is used by the customers to stand against the marketing tactics of the brands and its is regarded to be related with a scepticism both towards consumption idelogy and towards the general market. Just like the marketers neglecting all the moral values while trying to reach the goal, cynical the consumers can also have a potential of abusing other consumers (Kretz, 2010 as cited in Odou and Pechpeyrou, 2011:1799).

These statements of Pollay pay attention to the the viewpoint of advertisements in no noubt. When taken into consideration that today's consumers are more conscious and inquisitive than ever, we can easily say that the reliability levels of advertisements in the eyes of the consumers are not so high. That kind of feelings towards advertisements can be an important factor to trigger cynical attitudes.

The belief that advertisements are the instruments transmitting the messages exaggeratively are shared not only by the researchers but by the consumers as well. At that point (Pollay, 1986:29) states that 'Because virtually all citizens seem to recognize this tendency of advertisement language to distort, advertising seems to tum us into a community of cynics, and we doubt advertisers, the media, and authority in all its forms. Thus, we may also distrust other received wisdoms from political authorities, community elders, religious leaders, and teachers of all kinds' and again (Pollay, 1986:23) 'We like to think of ourselves as personally immune to advertising's inducements. This is clearly a delusion for some or perhaps many or even most of the public'. As it is seen cynical attitudes can be courced from different reasons.

Such a kind of negative attitude have some absolute impacts on the brand and the company as well. The consumers, losing confidence in the brand and having an opinion that the brands abuse the consumers, in other words cynical sonsumers, will have a high potiential to give harm to the brand or the company especially in this internet age. From the aspect of attitude, the unsatisfied consumers can react in a three-dimensional way. This reaction can sometimes be affective, sometimes cognitive and sometimes behavioural reaction.

The affective dimension is the negative feelings of the consumers about the brand or the company especially when they are sunsatisfied with the buying experiences in the market. So the disappointments following the unsatisfying consumption experiences and the negative feelings after that can be evaluated in the affective dimension of cynicism.

When it comes to the cognitive dimension of cynicism, we need to mention the beliefs in the consumers' minds that the brand or the company is unreliable, self-keeper and they never give up abusing the consumers. The reason here is that they have experienced disappointments repeatedly and their rights haven't been regarded as valuable (Bougie et al., 2003:389). 
Especially when they are convinced that the brand or the company itself is the responsible for their unsatisfying buying experiences, the consumers can exhibit some certain and usually predictable behaviours. This behavioural dimension, probably the most damaging one for the brand, can be seen in a variety of behavioural reactions. Those kinds of reactions can be seen in a variety of different forms from 'vigilant buying' to the actions of punishment attempts against the brand sometimes. All these behavioural reactions can be reflections of increasing cynicism in the consumers.

Among the reactive consumer behaviours are vigilant buying, complaint, negative wom, and revenge in the related literature. These reactions of cynical consumers are regarded as vital to analyse especially for their damaging potential on the brand (Forehand and Grier, 2003:349).

In more violent reactions, consumer rebellion or upheaval is another compensation or defence method for the cynical consumers. These kinds of reactions, which can be seen as violent protests (Lacayo, 1999:25), against the brand, sometimes reflect the necessity to correct the unethical behaviours of the brands and can even cause to buy second hand items rather than new ones. (Dobscha and Ozanne, 1998:95). This reaction is at the same time a protest against the marketing hype. (Chu and Chylinsky, 2006:2).

To sum up, consumer cynicism is a negative attitude of the consumers against the brand or the company. This attitude can be resulted from many different factors but whatever the reason is, its results can be so damaging for the brands. To be able to avoid cynical conusmers' damaging impacts, the companies must be able to deal with the reasons effectively. 